\title{
KEBERLANJUTAN \\ PERUMAHAN FORMAL DI KECAMATAN KEMILING BERDASARKAN KONSEP ECOLOGICAL HOUSING
}

\author{
Rima Yulia Mirhadi ${ }^{1}$, Sri Maryati ${ }^{2}$ \& Husna Tiara Putri ${ }^{1}$ \\ ${ }^{1}$ Program Studi Perencanaan Wilayah dan Kota, Institut Teknologi Sumatera \\ ${ }^{2}$ Program Studi Perencanaan Wilayah dan Kota, Institut Teknologi Bandung \\ Email: rimayuliamirhadi@gmail.com
}

DOI : 10.35472/jppk.v1i2.493

\begin{abstract}
Housing development in Indonesia generally more emphasized to built houses in term of quantity only rather than the quality. Thus, housing development sometimes neglect the sustainability aspect to meet the housing needs. Similiarly, Kemiling Sub District is a sub-district with limited housing/settlement regulation and has had housing since the 1980s, but new housing units are continue planned to be built. This study aims to determine the sustainability of formal housing in Kemiling District based on the concept of Ecological Housing. There are 2 targets to achieve these goals, namely: (1) Identifying the existing condition of formal housing in Kemiling District based on the concept of Ecological Housing, (2) Analyzing the condition of sustainability of Formal Housing in Kemiling District based on the concept of Ecological Housing. With descriptive analysis method and weighting analysis with Likert scale. The variables used are 7 variables, namely physical residential buildings, facilities, infrastructure, access to city facilities, environment, economy, social. Based on the results of the weighting analysis that has been carried out with the concept of Ecological Housing in Kemiling District categorized as 'good', then formal housing in Kemiling District can be sustainable.
\end{abstract}

Keywords: Ecological Housing Concept, Sustainable Housing, Formal Housing.

\section{A. PENDAHULUAN}

Rumah merupakan salah satu kebutuhan dasar sebagai tempat tinggal dalam melangsungkan kehidupan. Abrams dalam Kuswartojo (2005) mengatakan bahwa perumahan bukan hanya sekedar wadah tempat tinggal namun juga merupakan bagian dari komunitas dan lingkungan sosial. Ia juga menyatakan bahwa perumahan sangat erat kaitannya dengan aktivitas ekonomi, pembangunan, dan industrialisasi. Perkembangan perumahan di Indonesia sendiri cenderung padat khususnya di daerah perkotaan yang berkembang dengan sangat cepat. Dengan perkembangan di daerah perkotaan yang sangat cepat, maka perumahan cenderung dibuat terburu-buru untuk mengejar jumlah populasi yang meningkat seiring dengan berkembangnya suatu kota. Oleh karena itu pembangunan perumahan umumnya lebih ditekankan dari segi kuantitas saja agar dapat memenuhi kebutuhan akan rumah oleh masyarakat daripada kualitas rumah yang dibangun. Sehingga, dalam penyediaan perumahan terkadang mengabaikan aspek keberlanjutan, terutama dalam segi lingkungan perumahannya, yang dapat meningkatkan kemungkinan munculnya lingkungan perumahan yang tidak layak huni (Sabaruddin, 2016).

Perumahan yang berkelanjutan merupakan perumahan yang menerapkan 3 (tiga) pilar pembangunan berkelanjutan sehingga perumahan yang berkelanjutan mempertimbangkan aspek lingkungan, aspek ekonomi, dan aspek sosial (Sudarwanto, 2014). Ada beberapa konsep yang menerapkan prinsip sustainability, seperti Konsep 
Ecological Housing. Widja (2004) mengatakan bahwa ecological housing adalah suatu terapan dalam memanfaatkan sumber daya alam yang melimpah dengan fungsi dan kenyamanan rumah serta menekankan pada rumah yang memperhatikan potensi lingkungan di sekitarnya. Konsep ini tidak memfokuskan hanya pada kuantitas perumahannya saja ataupun kondisi dan desain fisik bangunannya. Tetapi, konsep ini bertujuan untuk menciptakan lingkungan perumahan yang aman dan nyaman tanpa melupakan kondisi lingkungan sekitarnya, sehingga kemungkinan kerusakan lingkungan dapat diminimalisir.

Seiring dengan berkembangnya suatu kota, kebutuhan akan rumah untuk menunjang aktivitas didalamnya juga terus meningkat. Kecamatan Kemiling merupakan Kecamatan dengan penduduk terbanyak. Peningkatan jumlah penduduk di Kecamatan Kemiling juga sangat pesat, terutama pada tahun 2020, yaitu 88.574 jiwa, yang mengalami peningkatan sebanyak 18.083 jiwa dari yang sebelumnya 70.491 jiwa. Dengan bertambahnya jumlah penduduk yang sangat pesat, maka kebutuhan akan rumah juga akan meningkat. Dengan meningkatnya kebutuhan akan rumah, maka diperlukan lahan baru untuk membangun tempat tinggal yang baru.

Dengan luas lahan yang besar yang berpotensi untuk dijadikan perumahan, maka menarik minat developer untuk terus membangun perumahan baru sehingga Kecamatan Kemiling berpotensi untuk terus berkembang dari segi perumahan. Perumahan formal sendiri merupakan perumahan yang dibangun oleh pemerintah ataupun perusahaan developer atau juga secara individual dengan tetap mengikuti sarana dan prasarana yang telah ditetapkan, sehingga memungkinkan lebih berkelanjutan karna sudah didesain dengan kriteria tertentu oleh pengembang.

Namun, pada RTRW Kota Bandar Lampung tertulis bahwa Kecamatan Kemiling merupakan kecamatan dengan perumahan/permukiman terbatas yang berarti pembangunan perumahan di Kecamatan Kemiling seharusnya dibatasi namun dapat dilihat bahwa pembangunan perumahan di Kecamatan Kemiling tetap berjalan dan terus direncanakan. Dalam RTRW Kota Bandar Lampung juga tertulis bahwa Kelurahan Beringin Raya, Kelurahan Sumber Agung, dan Kelurahan Kedaung termasuk dalam kawasan resapan air. Namun pada Kelurahan Beringin Raya terdapat 1 perumahan yang sangat besar dan padat, serta pada kelurahan Sumber Agung dan Kedaung banyak perumahan baru dibangun dan direncanakan akan dibangun. Dalam artikel lampost (2019), Perum Perumnas akan membangun perumahan baru non subsidi yaitu Cluster Mutiara di Kecamatan Kemiling. Banyak juga perumahan baru yang akan segera dibangun selain Cluster Mutiara saat peneliti melakukan survei lapangan. Selain itu dalam RTRW Kota Bandar Lampung juga dikatakan bahwa Kecamatan Kemiling rawan bencana tanah longsor. Sehingga konsep ecological housing tepat digunakan pada penelitian ini, dikarenakan konsep ini memfokuskan pada lingkungan perumahan.

Untuk tetap menjaga keberlanjutan perumahan yang sudah ada dan yang akan segera dibangun maka perlu adanya penilaian keberlanjutan perumahan formal di Kecamatan Kemiling untuk melihat apakah perumahan formal yang ada di Kecamatan Kemiling dapat terus memenuhi kebutuhan masyarakat tanpa melupakan aspek keberlanjutan perumahan.

Penelitian ini bertujuan untuk mengetahui keberlanjutan perumahan formal di 
Kecamatan Kemiling berdasarkan konsep Ecological Housing. Sasaran untuk mencapai tujuan dari penelitian ini yaitu: (1) Mengidentifikasi kondisi eksisiting perumahan formal di Kecamatan Kemiling berdasarkan konsep Ecological Housing; (2) Menganalisis kondisi keberlanjutan Perumahan Formal di Kecamatan Kemiling berdasarkan konsep Ecological Housing.

\section{B. METODE PENELITIAN}

Penelitian ini menggunakan pendekatan kuantitatif dengan 7 variabel utama yaitu: (1) fisik bangunan hunian; (2) sarana; (3) prasarana; (4) akses terhadap fasilitas kota; (5) lingkungan; (6) ekonomi; (7) sosial. Pada penelitian ini digunakan metode kuesioner dan observasi sebagai metode pengumpulan datanya. Dimana peneliti mengobservasi setiap perumahan yang kemudian akan dikonfirmasi ke narasumber penelitian. Dimana metode kuesioner ditujukan untuk setiap perumahan formal yang ada di Kecamatan Kemiling, dimana 1 kuesioner mewakilkan 1 perumahan formal. Narasumber biasanya dipilih berdasarkan masyarakat yang mengerti kondisi perumahan tersebut atau sudah tinggal cukup lama di perumahan tersebut. Seperti RT di perumahan, warga yang tinggal cukup lama ataupun developer perumahan itu sendiri. Narasumber akan ditanyakan mengenai kondisi eksisting perumahan yang ada berdasarkan konsep ecological housing. Jawaban yang diberikan oleh narasumber kemudian akan dikonfirmasi ulang kebenarannya oleh peneliti dengan melihat apakah jawaban yang diberikan oleh narasumber sesuai dengan kondisi sebenarnya.

Pada penelitian ini data yang dibutuhkan merupakan perumahan formal di Kecamatan Kemiling. Dikarenakan populasi dari perumahan formal di Kecamatan Kemiling tidak diketahui, meyebabkan adanya keterbatasan data dalam penelitian. Sehingga sampel perumahan formal diambil menggunakan pendekatan incidental sampling. Sampel disini merupakan bagian dari populasi yang ditemukan di area studi yaitu kecamatan kemiling dan dapat diakses oleh peneliti. Peneliti melakukan pengamatan pada wilayah studi untuk menukan sebaran perumahan. Setiap perumahan yang ditemukan kemudian dijadikan data sampel dengan catatan lokasi perumahan dapat dijangkau oleh peneliti.

Dalam tahap pengambilan data, peneliti menggunakan bantuan aplikasi Google Maps untuk menemukan perumahan yang ada di Kecamatan Kemiling. Selain itu, peneliti juga menyusuri jalan utama yang ada di Kecamatan Kemiling untuk menemukan perumahan. Berdasarkan hasil lapangan, didapatkan 21 perumahan formal di Kecamatan Kemiling, namun dalam penelitian ini hanya 20 perumahan yang dijadikan sampel dengan 20 responden yang dapat diambil dikarenakan perumahan yang tidak diambil yaitu De Royale Residence memiliki akses yang sulit untuk ke lokasi. Sehingga sampel penelitian ini berjumlah 20 perumahan.

Penelitian ini menggunakan analisis deskriptif dan analisis scoring dengan skala likert dan rumus stugers untuk menentukan kelasnya yaitu $k=1+3,322 \log n$. Sehingga didapat 4 dengan jumlah variable yang digunakan yaitu 7 variabel. Kelas yang digunakan yaitu Sangat Baik, Baik, Cukup, Buruk 


\section{HASIL DAN PEMBAHASAN}

\section{Karakteristik Perumahan Formal di Kecamatan Kemiling}

Perumahan formal di Kecamatan Kemiling tersebar di seluruh kelurahan yang ada di Kecamatan Kemiling. Untuk perumahan terbesar yang ada di Kecamatan Kemiling yaitu Perumnas Bukit Kemiling Permai atau biasa disebut sebagai Perumnas BKP yang dibangun oleh developer BUMN yaitu Perumnas BKP yang tersebar di Kelurahan Kemiling Permai dan Kelurahan Kemiling Raya. Setelah Perumnas BKP, perumahan dengan skala besar lainnya yaitu Perumahan Beringin Raya yang dibangun oleh developer PT Sinar Waluyo yang tersebar di keluaran Beringin Raya dan Beringin Jaya. Untuk perumahan di kelurahan lain seperti Kelurahan Sumberejo, Kelurahan Sumberejo Sejahtera dan Kelurahan Pinang Jaya ada cenderung merupakan perumahan non formal yang dibangun oleh individu ataupun keluarga. Sedangkan untuk kelurahan Sumber Agung dan kelurahan Kedaung banyak perumahan-perumahan baru dibangun dan direncanakan untuk dibangun karna masi banyak lahan kosong.

Terdapat 20 perumahan yang tersebar di seluruh Kecamatan Kemiling yang akan digunakan dalam penelitian ini. Dengan 9 perumahan sederhana, 10 perumahan menengah, dan 1 perumahan mewah. Berikut tabel sebaran perumahan di Kecamatan Kemiling yang dapat dilihat pada table 1 .

Tabel 1. Sebaran Perumahan di Kecamatan Kemiling

\begin{tabular}{|l|c|}
\hline Kelurahan & Perumahan \\
\hline Sumber Agung & 2 \\
\hline Kedaung & 5 \\
\hline Pinang Jaya & 1 \\
\hline Beringin Raya & 4 \\
\hline Sumber Rejo & 1 \\
\hline Kemiling Permai & 1 \\
\hline Sumber Rejo Sejahtera & 2 \\
\hline Beringin Jaya & 2 \\
\hline Kemiling Raya & 2 \\
\hline TOTAL & $\mathbf{2 0}$ \\
\hline
\end{tabular}

Sumber: Hasil survei, 2021
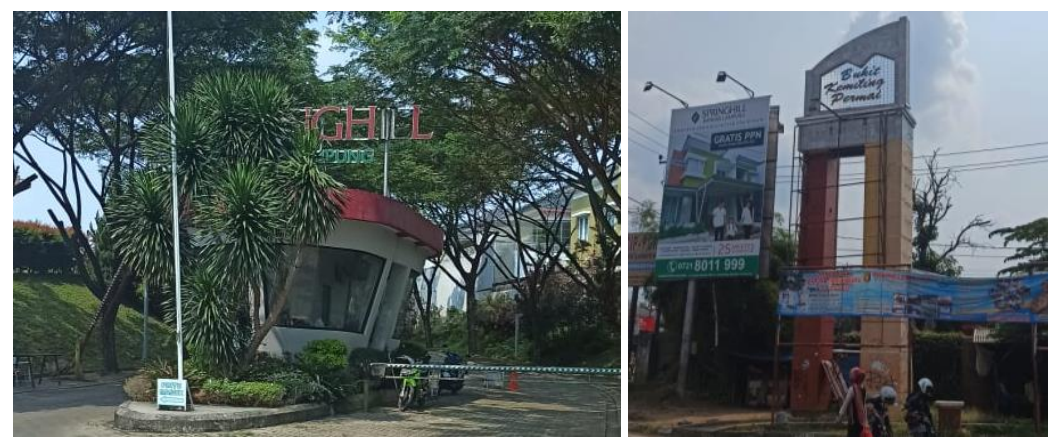

Sumber: hasil survei, 2021

Gambar 1. Perumahan di Kecamatan Kemiling 


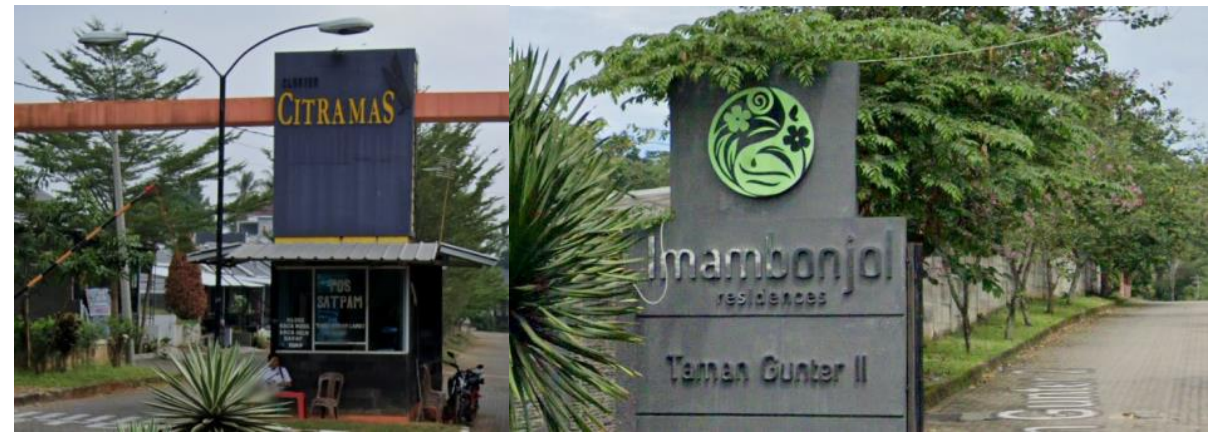

Sumber: hasil survei, 2021

Gambar 1. Perumahan di Kecamatan Kemiling

Berdasarkan hasil survei yang telah dilakukan, terdapat kesamaan pada setiap jenis perumahan yang kemudian dapat dibagi menjadi 3 golongan yaitu perumahan sederhana, menengah, dan mewah. Perumahan sederhana umumnya merupakan perumahan dengan tipe yang sederhana dan dengan sebagian besar sasaran penghuni rumah bersubsidi. Kisaran harga perumahan sederhana mulai dari 80 juta rupiah s.d. 250 juta rupiah. Sedangkan untuk perumahan menengah umumnya merupakan perumahan yang memiliki fasilitas dasar yang cukup lengkap dengan kisaran harga perumahan mulai dari 300 juta rupiah s.d. 700 juta rupiah. Kemudian, untuk perumahan mewah sendiri merupakan perumahan yang memiliki fasilitas yang cukup lengkap serta akses keluar masuk perumahan yang terbatas hanya untuk penghuni perumahan saja dengan keamanan yang cukup ketat pula.

\section{Kondisi Eksisting Perumahan Formal di Kecamatan Kemiling}

\section{- Fisik Bangunan Hunian}

Untuk melihat keberlanjutan dari segi aspek fisik bangunan hunian perumahan formal di Kecamatan Kemiling, maka dilakukan analisis pembobotan setiap sub variabel yaitu hemat energi, taman, pencahayaan alami, dan kokoh.

Tabel 2. Kondisi Aspek Fisik Bangunan Hunian

\begin{tabular}{|c|l|}
\hline Turunan Variabel & \multicolumn{1}{|c|}{ Hasil } \\
\hline Hemat energi & Tidak ada yang menggunakan teknologi hemat energi \\
\hline Taman & 5\% perumahan dengan seluruh rumah tidak ada yang dilengkapi taman, \\
& 70\% perumahan dengan seluruh rumah beberapa yang dilengkapi taman, \\
& 20\% perumahan dengan seluruh rumah kebanyakan yang dilengkapi \\
& taman, \\
& $5 \%$ semua perumahan dengan seluruh rumah yang dilengkapi taman \\
\hline Pencahayaan alami & Semua rumah dalam perumahan memiliki jendela \\
\hline Kokoh & Semua rumah dalam perumahan mempunyai bangunan yang kokoh \\
\hline
\end{tabular}

Sumber: Hasil analisis, 2021

Tabel 3. Pembobotan Aspek Fisik Bangunan Hunian

\begin{tabular}{|l|c|c|}
\hline \multicolumn{1}{|c|}{ Sub Variabel } & Skor & Kelas \\
\hline Hemat Energi & 20 & Kurang \\
\hline taman & 45 & Cukup \\
\hline
\end{tabular}




\begin{tabular}{|l|c|c|}
\hline \multicolumn{1}{|c|}{ Sub Variabel } & Skor & Kelas \\
\hline Pencahayaan Alami & 80 & Sangat Baik \\
\hline Kokoh & 80 & Sangat Baik \\
\hline RATA-RATA & $\mathbf{5 6 , 2 5}$ & Baik \\
\hline
\end{tabular}

Sumber: Hasil analisis, 2021

Berdasarkan tabel 2 dan tabel 3, dapat dilihat bahwa perumahan formal di Kecamatan Kemiling dari segi aspek fisik bangunan hunian memiliki rata-rata skor 56,25 yang dikategorikan 'baik'. Dari 4 hasil analisis sub variabel yang ada, untuk sub variabel hemat energi memiliki skor 20 yang dikategorikan 'kurang' dikarenakan tidak ada perumahan di Kecamatan Kemiling yang menggunakan teknologi hemat energi. Kemudian, untuk sub variabel taman memiliki skor 45 yang dikategorikan 'cukup'. Lalu sub variabel pencahayaan alami memiliki skor maksimal yaitu 80 sehingga dikategorikan 'sangat baik'. Terakhir, sub variabel kokoh juga memilki skor yang maksimal yaitu 80 sehingga dikategorikan 'sangat baik'.

\section{- Sarana}

Untuk melihat keberlanjutan dari segi sarana perumahan formal di Kecamatan Kemiling, maka dilakukan analisis pembobotan setiap sub variabel yaitu sarana kesehatan, sarana pendidikan dasar, sarana peribadatan, dan sarana perniagaan dan perbelanjaan.

Tabel 4. Kondisi Sarana

\begin{tabular}{|c|l|}
\hline Turunan Variabel & \multicolumn{1}{|c|}{ Hasil } \\
\hline Sarana Kesehatan & $\begin{array}{l}25 \%>1 \mathrm{~km} \text { dari perumahan untuk menemukan fasilitas } \\
\text { kesehatan, }\end{array}$ \\
& $10 \% 500 \mathrm{~m}$ dari perumahan untuk menemukan fasilitas \\
& kesehatan, \\
& $15 \%$ 200m dari perumahan untuk menemukan fasilitas \\
& kesehatan, \\
& $50 \%$ perumahan dekat sarana kesehatan \\
\hline Sarana Pendidikan & $20 \%>1 \mathrm{~km}$ dari perumahan untuk menemukan fasilitas \\
Dasar & pendidikan dasar, \\
& $20 \% 500 \mathrm{~m}$ dari perumahan untuk menemukan fasilitas \\
& pendidikan dasar, \\
& $5 \% 200 \mathrm{~m}$ dari perumahan untuk menemukan fasilitas \\
& pendidikan dasar, \\
& $55 \%$ perumahan dekat sarana pendidikan dasar \\
\hline Sarana Peribadatan & $5 \% 200 \mathrm{~m}$ dari perumahan untuk menemukan fasilitas \\
& peribadatan, \\
& $95 \%$ perumahan dekat sarana peribadatan \\
\hline Sarana Perniagaan & $45 \%>1 \mathrm{~km}$ dari perumahan untuk menemukan pasar, \\
Dan Perbelanjaan & $15 \% 500 \mathrm{~m}$ dari perumahan untuk menemukan pasar, \\
& $15 \%$ 200m dari perumahan untuk menemukan pasar, \\
& $25 \%$ perumahan dekat pasar \\
\hline
\end{tabular}

Sumber: Hasil analisis, 2021

Tabel 5. Pembobotan Sarana

\begin{tabular}{|l|c|c|}
\hline \multicolumn{1}{|c|}{ Sub Variabel } & Skor & Kelas \\
\hline Sarana Kesehatan & 58 & Baik \\
\hline Sarana Pendidikan Dasar & 59 & Baik \\
\hline
\end{tabular}




\begin{tabular}{|l|c|c|}
\hline \multicolumn{1}{|c|}{ Sub Variabel } & Skor & Kelas \\
\hline Sarana Peribadatan & 79 & Sangat Baik \\
\hline Sarana Perniagaan dan Perbelanjaan & 44 & Cukup \\
\hline RATA-RATA & $\mathbf{6 0}$ & Baik \\
\hline
\end{tabular}

Sumber: Hasil analisis, 2021

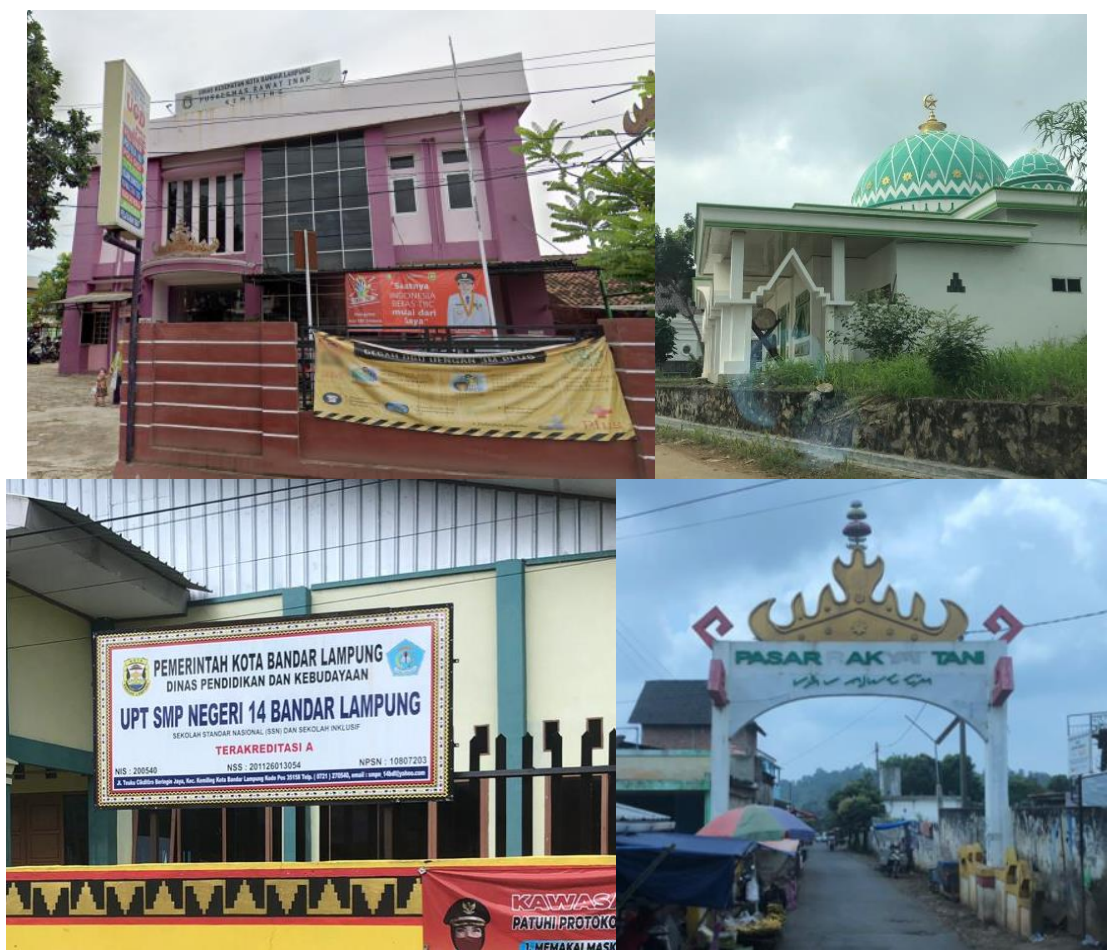

Sumber: Hasil survei, 2021

Gambar 2. Sarana di Kecamatan Kemiling

Berdasarkan tabel 4 dan tabel 5, dapat dilihat bahwa perumahan formal di Kecamatan Kemiling dari segi sarana memiliki rata-rata skor $\mathbf{6 0}$ yang dikategorikan 'baik'. Dari 4 hasil analisis sub variabel yang ada, untuk sub variabel sarana kesehatan memiliki skor 58 yang dikategorikan 'baik'. Kemudian, untuk sub variabel sarana pendidikan dasar memiliki skor 59 yang dikategorikan 'baik'. Lalu sub variabel sarana peribadatan memiliki skor hampir maksimal yaitu 79 sehingga dikategorikan 'sangat baik'. Terakhir, sub variabel sarana perniagaan dan perbelanjaan memilki skor 44 sehingga dikategorikan 'cukup'.

\section{- Prasarana}

Untuk melihat keberlanjutan dari segi prasarana perumahan formal di Kecamatan Kemiling, maka dilakukan analisis pembobotan setiap sub variabel yaitu penerangan jalan, akses air bersih, jaringan air bersih, sanitasi, jaringan persampahan, jaringan drainase, pengelolaan limbah, dan jaringan listrik 
Tabel 6. Kondisi Prasarana

\begin{tabular}{|c|l|}
\hline Turunan Variabel & \multicolumn{1}{c|}{ Hasil } \\
\hline Penerangan jalan & Semua rumah dalam perumahan memiliki penerangan jalan \\
\hline Akses air bersih & Semua rumah dalam perumahan memiliki akses air bersih \\
\hline Jaringan air bersih & Semua rumah dalam perumahan memiliki kualitas air yang baik \\
\hline Sanitasi & Semua rumah dalam perumahan memiliki MCK \\
\hline Jaringan persampahan & $\begin{array}{l}\text { Semua rumah dalam perumahan sudah terlayani pengangkutan } \\
\text { sampah }\end{array}$ \\
\hline Jaringan drainase & $\begin{array}{l}10 \% \text { perumahan dengan seluruh rumah beberapa tergenang, 90\% } \\
\text { tidak ada perumahan yang rumahnya tergenang }\end{array}$ \\
\hline Pengelolaan limbah & Semua rumah dalam perumahan memiliki septictank \\
\hline Jaringan listrik & Semua rumah dalam perumahan sudah teraliri listrik \\
\hline
\end{tabular}

Sumber: Hasil analisis, 2021

Tabel 7. Pembobotan Prasarana

\begin{tabular}{|l|c|c|}
\hline \multicolumn{1}{|c|}{ Sub Variabel } & Skor & Kelas \\
\hline Penerangan Jalan & 80 & Sangat Baik \\
\hline Akses Air Bersih & 80 & Sangat Baik \\
\hline Jaringan Air Bersih & 80 & Sangat Baik \\
\hline Sanitasi & 80 & Sangat Baik \\
\hline Jaringan Persampahan & 80 & Sangat Baik \\
\hline Jaringan Drainase & 78 & Sangat Baik \\
\hline Pengelolaan Limbah & 80 & Sangat Baik \\
\hline Jaringan Listrik & 80 & Sangat Baik \\
\hline RATA-RATA & $\mathbf{7 9 , 7 5}$ & Sangat Baik \\
\hline
\end{tabular}

Sumber: Hasil analisis, 2021

Berdasarkan tabel 6 dan tabel 7, dapat dilihat bahwa perumahan formal di Kecamatan Kemiling dari segi prasarana memiliki rata-rata skor hampir maksimal yaitu 79,75 sehingga dikategorikan 'sangat baik'. Dari 8 sub variabel yang ada, semua memiliki skor maksimal yaitu 80 sehingga dikategorikan 'sangat baik' kecuali jaringan drainase yang memiliki skor 78 tetapi masi dikategorikan 'sangat baik'. Hal ini dikarenakan semua perumahan formal terpenuhi dengan baik kebutuhan dasarnya, hanya ada beberapa rumah saja dalam suatu perumahan yang terjadi genangan untuk waktu yang singkat apabila terjadi hujan lebat.

\section{- Akses Terhadap Fasilitas Kota}

Untuk melihat keberlanjutan dari segi akses terhadap fasilitas kota perumahan formal di Kecamatan Kemiling, maka dilakukan analisis pembobotan setiap sub variabel yaitu keberadaan transportasi publik dan kesediaan masyarakat

Tabel 8. Kondisi Akses Terhadap Fasilitas Kota

\begin{tabular}{|c|l|}
\hline Turunan Variabel & Hasil \\
\hline Keberadaan transportasi & $40 \%>1 \mathrm{~km}$ dari perumahan untuk menemukan angkutan publik, \\
publik & $25 \% 500 \mathrm{~m}$ dari perumahan untuk menemukan angkutan publik, \\
& $20 \%$ 200m dari perumahan untuk menemukan angkutan publik, \\
& $15 \%$ perumahan dilalui angkutan publik \\
\hline Kesediaan masyarakat & $50 \%$ tidak ada yang bersedia, 50\% beberapa bersedia \\
\hline
\end{tabular}

Sumber: Hasil analisis, 2021 
Tabel 9. Pembobotan Akses Terhadap Fasilitas Kota

\begin{tabular}{|l|c|c|}
\hline \multicolumn{1}{|c|}{ Sub Variabel } & Skor & Kelas \\
\hline Keberadaan Transportasi Publik & 42 & Cukup \\
\hline Kesediaan Masyarakat & 30 & Kurang \\
\hline RATA-RATA & $\mathbf{3 6}$ & Cukup \\
\hline
\end{tabular}

Sumber: Hasil analisis, 2021

Berdasarkan tabel 8 dan tabel 9, dapat dilihat bahwa perumahan formal di Kecamatan Kemiling dari segi akses terhadap fasilitas kota memiliki rata-rata skor $\mathbf{3 6}$ sehingga dikategorikan sebagai 'cukup'. Dari 2 sub variabel yang ada, untuk sub variabel keberadaan transportasi publik memiliki skor 42 dan dikategorikan sebagai 'cukup'. Dan untuk sub variabel kesediaan masyarakat memiliki skor 30 dan dikategorikan sebagai 'kurang' yang dikarenakan penghuni lebih memilih menggunakan kendaraan pribadi ataupun ojek online.

\section{- Lingkungan}

Untuk melihat keberlanjutan dari segi lingkungan perumahan formal di Kecamatan Kemiling, maka dilakukan analisis pembobotan setiap sub variabel yaitu public space.

Tabel 10. Kondisi Lingkungan

\begin{tabular}{|c|l|}
\hline Turunan Variabel & \multicolumn{1}{c|}{ Hasil } \\
\hline \multirow{3}{*}{ Public space } & 5\% kurang multifungsi ruang publik, \\
& $55 \%$ minim multifungsi ruang publik, \\
& $40 \%$ multifungsi public space juga untuk kebutuhan sekunder \\
\hline
\end{tabular}

Sumber: Hasil analisis, 2021

Tabel 11. Pembobotan Lingkungan

\begin{tabular}{|l|c|c|}
\hline \multicolumn{1}{|c|}{ Sub Variabel } & Skor & Kelas \\
\hline Public Space & 47 & Cukup \\
\hline RATA-RATA & $\mathbf{4 7}$ & Cukup \\
\hline
\end{tabular}

Sumber: Hasil analisis, 2021

Berdasarkan tabel 10 dan tabel 11, dapat dilihat bahwa perumahan formal di Kecamatan Kemiling dari segi lingkungan perumahannya memiliki skor rata-rata $\mathbf{4 7}$ dan dikategorikan sebagai 'cukup'. Hal ini dapat dikarenakan multifungsi public space masih kurang di setiap perumahan terutama perumahan subsidi.

\section{- Ekonomi}

Untuk melihat keberlanjutan dari segi ekonomi perumahan formal di Kecamatan Kemiling, maka dilakukan analisis pembobotan setiap sub variabel yaitu produktivitas berdasarkan pekerjaan dan pemanfaatan fungsi rumah.

Tabel 12. Kondisi Ekonomi

\begin{tabular}{|c|l|}
\hline Turunan Variabel & \multicolumn{1}{|c|}{ Hasil } \\
\hline Produktivitas & $10 \%$ perumahan yang penghuninya beberapa yang bekerja di sekitar, \\
penghuni (1) & 85\% perumahan yang penghuninya kebanyakan yang bekerja di sekitar, \\
& $5 \%$ perumahan yang semua penghuninya yang bekerja di sekitar \\
\hline Produktivitas & $\begin{array}{l}10 \% \text { perumahan yang tidak ada penghuninya yang memanfaatkan juga } \\
\text { pebagai tempat bisnis, }\end{array}$ \\
\hline
\end{tabular}




\begin{tabular}{|c|l|}
\hline Turunan Variabel & \multicolumn{1}{c|}{ Hasil } \\
\hline & $\begin{array}{c}\text { 25\% perumahan yang penghuninya ada yang memanfaatkan juga sebagai } \\
\text { tempat bisnis, }\end{array}$ \\
& $\begin{array}{l}\text { 40\% perumahan yang beberapa penghuninya yang memanfaatkan juga } \\
\text { sebagai tempat bisnis, } \\
\text { 25\% perumahan yang sebagian penghuninya memanfaatkan juga sebagai } \\
\text { tempat bisnis }\end{array}$ \\
\hline Kekeluargaan & $10 \%$ perumahan yang tidak ada aktivitas gotong royong, \\
masyarakat (1) & $30 \%$ perumahan yang aktivitas gotong royong terjadi hanya pada \\
& keadaan darurat, \\
& 40\% perumahan yang gotong royong sesekali, \\
& $20 \%$ perumahan yang gotong royong rutin \\
\hline
\end{tabular}

Sumber: Hasil analisis, 2021

Tabel 13. Pembobotan Ekonomi

\begin{tabular}{|l|c|c|}
\hline \multicolumn{1}{|c|}{ Sub Variabel } & Skor & Kelas \\
\hline Produktivitas (1) & 59 & Baik \\
\hline Produktivitas (2) & 56 & Baik \\
\hline RATA-RATA & $\mathbf{5 7 , 5}$ & Baik \\
\hline
\end{tabular}

Sumber: Hasil analisis, 2021

Berdasarkan tabel 12 dan tabel 13, dapat dilihat bahwa perumahan formal di Kecamatan Kemiling dari segi ekonomi perumahannya memiliki skor rata-rata 57,5 dan dikategorikan sebagai 'baik'. Dilihat dari sub variabel produktivitas yang terbagi menjadi 2 yaitu produktivitas berdasarkan pekerjaan dan berdasarkan pemanfaatan fungsi rumah, keduanya memiliki skor 59 dan 56 sehingga dapat dikategorikan 'baik' .

\section{- Sosial}

Untuk melihat keberlanjutan dari segi sosial perumahan formal di Kecamatan Kemiling, maka dilakukan analisis pembobotan setiap sub variabel yaitu kekeluargaan masyarakat dari segi gotong royong dan partisipasi penghuninya serta interaksi antar masyarakat.

Tabel 14. Kondisi Sosial

\begin{tabular}{|c|l|}
\hline Turunan Variabel & \multicolumn{1}{|c|}{ Hasil } \\
\hline Kekeluargaan & $10 \%$ perumahan yang tidak ada aktivitas gotong royong, \\
masyarakat (1) & $30 \%$ perumahan yang aktivitas gotong royong terjadi hanya pada keadaan \\
& darurat, \\
& $40 \%$ perumahan yang gotong royong sesekali, \\
& $20 \%$ perumahan yang gotong royong rutin \\
\hline Kekeluargaan & $10 \%$ perumahan yang penghuninya tidak ada yang tertarik untuk terlibat, \\
masyarakat (2) & $35 \%$ perumahan yang beberapa penghuninya tertarik untuk terlibat, \\
& 25\% perumahan yang kebanyakan penghuninya tertarik untuk terlibat, \\
& $30 \%$ perumahan yang semua penghuninya tertarik untuk terlibat \\
\hline \multirow{2}{*}{ Interaksi Masyarakat } & $\begin{array}{l}35 \% \text { perumahan yang beberapa penghuninya saling berinteraksi, 55\% } \\
\text { perumahan yang kebanyakan penghuninya saling berinteraksi }\end{array}$ \\
\hline
\end{tabular}

Sumber: Hasil analisis, 2021 
Tabel 15. Pembobotan Sosial

\begin{tabular}{|l|c|c|}
\hline \multicolumn{1}{|c|}{ Sub Variabel } & Skor & Kelas \\
\hline Kekeluargaan Masyarakat (1) & 54 & Baik \\
\hline Kekeluargaan Masyarakat (2) & 55 & Baik \\
\hline Interaksi Masyarakat & 53 & Baik \\
\hline RATA-RATA & $\mathbf{5 4}$ & Baik \\
\hline
\end{tabular}

Sumber: Hasil analisis, 2021

Berdasarkan tabel 14 dan tabel 15, dapat dilihat bahwa perumahan formal di Kecamatan Kemiling dari segi sosial perumahannya memiliki skor rata-rata 54 dan dikategorikan sebagai 'baik'. Dilihat dari 2 sub variabel yang ada, dimana sub variabel kekeluargaan masyarakat terbagi menjadi 2 yaitu berdasarkan adanya aktivitas gotong royong dan keterlibatan masyarakat dalam aktivitas gotong royong memiliki skor 54 dan 55, sehingga dikategorikan 'baik'. Kemudian untuk sub variabel interaksi masyarakat juga dikategorikan ‘baik' dengan skor 53.

\section{Keberlanjutan Perumahan Formal di Kecamatan Kemiling}

Untuk melihat keterkaitan dari seluruh variabel yang ada maka perlu dilihat seluruh hasil pembobotan yang kemudian akan dicari rata-rata dari setiap skor tiap variabel yang ada. Hasil pembobotan dari seluruh variabel dapat dilihat pada tabel dan grafik berikut.

Tabel 16. Kondisi Eksisting Perumahan Formal

\begin{tabular}{|l|c|c|}
\hline \multicolumn{1}{|c|}{ Sub Variabel } & Skor & Kelas \\
\hline Aspek Fisik Bangunan Hunian & 56,25 & Baik \\
\hline Sarana & 60 & Baik \\
\hline Prasarana & 79,75 & Sangat Baik \\
\hline Akses Terhadap Fasilitas Kota & 36 & Cukup \\
\hline Lingkungan & 47 & Cukup \\
\hline Ekonomi & 57,5 & Baik \\
\hline Sosial & 54 & Baik \\
\hline RATA-RATA & $\mathbf{5 5 , 8}$ & Baik \\
\hline
\end{tabular}

Sumber: Hasil analisis, 2021

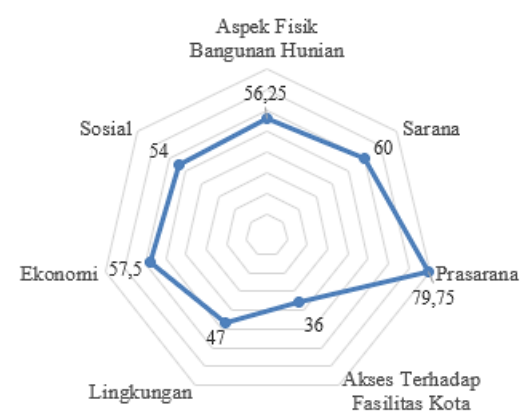

Sumber: Hasil analisis, 2021

Gambar 3. Grafik Radar Kondisi Eksisting per Variabel

Berdasarkan tabel 16 dan gambar 1 dapat dilihat hasil skor seluruh 7 variabel yang memengaruhi keberlanjutan suatu perumahan. Variabel aspek fisik bangunan hunian memiliki skor 56,25 sehingga dikategorikan sebagai 'baik'. Kemudian variabel sarana memiliki skor 60 sehingga dikategorikan sebagai 'baik'. Sedangkan variabel prasarana 
memiliki skor 79,75 yang kemudian dikategorikan sebagai 'sangat baik'. Untuk variabel akses terhadap fasilitas kota memiliki skor 36 sehingga dikategorikan sebagai 'cukup'. Pada variabel lingkungan memiliki skor 47 sehingga dikategorikan sebagai 'cukup'. Lalu untuk variabel ekonomi memiliki skor 57,5 sehingga dikategorikan sebagai 'baik'. Dan terakhir variabel sosial memiliki skor 54 sehingga dikategorikan sebagai 'baik'. Dari hasil pembobotan setiap variabel yang kemudian ditarik rata-rata skor dari seluruh variabel didapat skor 55,8 yang berarti perumahan formal di Kecamatan Kemiling dilihat dari sisi keberlanjutan berdasarkan konsep ecological housing dikategorikan sebagai 'baik'.

Berdasarkan hasil yang pembobotan yang ada, variabel akses terhadap fasilitas kota dan variabel lingkungan masih dikategorikan sebagai 'cukup'. Dari segi akses terhadap fasilitas kota, masyarakat Kecamatan Kemiling lebih memilih untuk menggunakan transportasi pribadi daripada angkutan umum. Sedangkan untuk segi lingkungan yang dilihat dari keberadaan 'public space' di setiap perumahan yang masih minim.

Setelah melihat keberlanjutan perumahan formal di Kecamatan Kemiling dari setiap variabel yang memengaruhi keberlanjutannya, maka dapat dilihat pula keberlanjutan dari setiap perumahan formal yang ada di Kecamatan Kemiling. Berikut diagram hasil analisis pembobotannya.

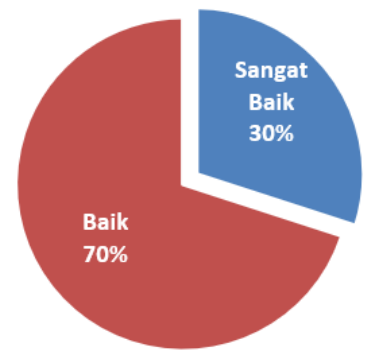

Sumber: Hasil analisis, 2021

Gambar 4. Diagram Persentase Keberlanjutan Perumahan Formal

Berdasarkan diagram pada gambar 2, 6 dari 20 perumahan formal yang ada di Kecamatan Kemiling mendapatkan skor yang dikategorikan 'sangat baik'. Perumahan yang dikategorikan 'sangat baik' yaitu Perumnas BKP yang ada di Kelurahan Kemiling Permai dengan skor 81, Perumahan Pinang Jaya yang ada di Kelurahan Pinang Jaya dengan skor 80, Springhill Residence yang ada di Kelurahan Kemiling Raya juga dengan skor 80, Perumahan Wisma Mas A yang berada di Kelurahan Sumberejo Sejahtera dengan skor 80, Perumahan Polda 1 yang ada di Kelurahan Beringin Raya dengan skor 79, dan terakhir Perumahan Polda 2 yang ada di Kelurahan Beringin Raya dengan skor 79.

Selanjutnya, untuk 14 perumahan formal lainnya yang ada di Kecamatan Kemiling mendapatkan skor yang dikategorikan 'baik'. Perumahan yang dikategorikan 'baik' yaitu Budaya Residence yang ada di Kelurahan Sumberejo dengan skor 78, Perumahan Wana Asri yang ada di Kelurahan Beringin Jaya dengan skor 78, Perumahan Wisma Mas B yang ada di Kelurahan Beringin Raya dengan skor 78, Perumahan Beringin Raya yang ada di Kelurahan Beringin Raya denga skor 77, Cluster Citramas yang ada di Kelurahan Kemiling Raya dengan skor 76, Perumahan Taman Gunter II yang ada di Kelurahan 
Sumberejo Sejahtera dengan skor 76, Perumahan Griya Fitra Insani yang ada di Kelurahan Kedaung dengan skor 72, Perumahan Anugrah Jaya Indah yang ada di Kelurahan Sumber Agung dengan skor 72, Perumahan Griya Annisa Kedaung yang ada di Kelurahan Kedaung dengan skor 71, Perumahan Bhayangkara Kemiling yang ada di Kelurahan Beringin Jaya dengan skor 71, Perumahan Alivia yang ada di Kelurahan Sumber Agung dengan skor 69, Sakura Residence yang ada di Kelurahan Kedaung dengan skor 67, Perumahan Kedaung Jaya Indah yang ada di Kelurahan Kedaung dengan skor 67, dan terakhir Green Kemiling Residence yang ada di Kelurahan Kedaung dengan skor 65 .

Dari hasil pembobotan setiap perumahan yang kemudian ditarik rata-rata skor dari seluruh perumahan didapat skor $\mathbf{7 4 , 8}$ yang berarti perumahan formal di Kecamatan Kemiling dilihat dari sisi keberlanjutannya berdasarkan konsep ecological housing dikategorikan sebagai 'baik'.

\section{KESIMPULAN}

Untuk mengetahui keberlanjutan perumahan formal di Kecamatan Kemiling berdasarkan konsep Ecological Housing. Dengan hasil dari analisis pembobotan yang telah dilakukan dengan konsep Ecological Housing Kecamatan Kemiling dikategorikan sebagai 'baik', maka perumahan formal di Kecamatan Kemiling dapat berkelanjutan. Hal ini yang menjadi alasan mengapa developer perumahan formal di Kecamatan Kemiling terus merencanakan pembangunan perumahan baru karena Kecamatan Kemiling berpotensi untuk terus berkembang dari segi perumahan.

\section{DAFTAR PUSTAKA}

[1] Brundtland, G. H. (1987). Our Common Future: Report of the World Commission on Environment and Development. Oxford: Oxford University Press.

[2] Kuswartojo, T., dkk. (2005). Perumahan dan Pemukiman di Indonesia: Upaya membuat perkembangan kehidupan yang berkelanjutan. Bandung: Penerbit ITB.

[3] Lampost. (2019, March 11). Perumnas Bersiap Luncurkan Cluster Mutiara BKP. Diambil kembali dari Lampost.Co Jendela Informasi Lampung: https://m.lampost.co/berita-perumnas-bersiap-luncurkan-cluster-mutiara-bkp.html

[4] Murniningtyas, E. (2014). Prakarsa Strategis Pengembangan Konsep Green Economy. Jakarta: Badan Perencanaan Pembangunan Nasional.

[5] Razan, S. S., \& Yuliastuti, N. (2004). Penilaian Kualitas Perumnas Banyumanik Ditinjau Dari Konsep Ecological Housing. Jurnal Teknik PWK, 3 (1), 187-197.

[6] Sabaruddin, A. (2016). Permukiman Berkelanjutan: Telaah Psikologi Sosial. Jakarta: Penerbit Erlangga.

[7] Sudarwanto, B., Edward, P. E., \& Soetomo, S. (2014, Desember). Pencapaian Perumahan Berkelanjutan 'Pemilihan Indikator Dalam Penyusunan Kerangka Kerja Berkelanjutan'. MODUL, 14(2).

[8] Tosics, I. (2004). European urban development: Sustainability and the role of housing. Journal of Housing and the Built Environment, 19, 67-90.

[9] Widja, I. (2004). Eco House Pada Perkembangan Rumah Tradisional Bali. Jurnal Permukiman Natah, 2(1), 1-55. 